\title{
A Rare Complication Following Adenotonsillectomy: Grisel's Syndrome
}

\author{
Niyazi Altıntoprak, ${ }^{1}$ Kübra Murzoğlu Altıntoprak, ${ }^{2}$ Furkan Keskin, ${ }^{3}$ Öner Çelik
}

\author{
'Department of Ear Nose Thorat, \\ Maltepe University Faculty of \\ Medicine, İstanbul, Turkey \\ ${ }^{2}$ Department of Radiology, Maltepe \\ University Faculty of Medicine, \\ İstanbul, Turkey \\ ${ }^{3}$ Term 5 Student, Maltepe University \\ Faculty of Medicine, İstanbul, Turkey \\ Submitted: 28.12.2017 \\ Accepted: 19.03.2018 \\ Correspondence: Niyazi Altıntoprak, \\ Maltepe Üniversitesi Tıp Fakültesi \\ Hastanesi, Kulak Burun Boğaz \\ Anabilim Dalı, İstanbul, Turkey \\ E-mail: niyazialt@gmail.com

aring \\ Keywords: Atlantoaxial \\ subluxation; \\ Grisel's syndrome; torticollis.
}

\begin{abstract}
The nontraumatic subluxation of the atlantoaxial joint, also called Grisel's syndrome, is a rarely seen phenomenon in the pediatric population after nasopharyngeal inflammation or otolaryngological surgery. The patients are usually between 5 and 12 years old, and there is no gender difference in occurrence. Grisel's syndrome should be considered in patients who have painful torticollis after an upper airway infection or otolaryngological surgery. The most important factor affecting the prognosis is early diagnosis and treatment. Early diagnosis not only allows for conservative treatment, but it also prevents permanent neck deformity and the development of severe neurological deficit and morbidity due to extensive surgical procedures. Otolaryngologists should be aware of this rare, but potentially serious, condition.
\end{abstract}

\section{INTRODUCTION}

Nontraumatic atlantoaxial rotatory subluxation was first described by Charles Bell in 1830 in a patient with syphilis and pharyngitis. Grisel defined it as a syndrome in 1951. Grisel's syndrome is atlantoaxial rotatory subluxation that occurs after a previous infection or otolaryngological surgery other than trauma. ${ }^{[1]}$

Children are more often affected; patients are usually between 5 and 12 years old. There is no gender difference in occurrence. Patients typically have torticollis with neck stiffness or painful neck movements. Torticollis may occur related to pharyngitis or after a slight trauma to the neck. This syndrome has been reported to be associated with surgical procedures, such as mastoidectomy, adenotonsillectomy, choanal atresia repair, and other situations, like rhinopharyngitis, cervical osteomyelitis, and rheumatological diseases. Tension or abnormal laxity of the ligaments around the atlantoaxial joint resulting from direct expansion of pharyngeal or nasopharyngeal inflammation can cause neurological damage or cervical spine instability. ${ }^{[2]}$

\section{CASE REPORT}

An 8-year-old boy was brought by his parents to the clinic with complaints of recurrent tonsillitis, nasal obstruction, and snoring for three years. An otolaryngological examination revealed that both palatine tonsils were quite large with adenoid tissue closely covering the choana, while the bilateral tympanic membranes were normal in appearance. Other systemic examinations were within the normal limits. The patient was diagnosed as having chronic adenotonsillitis with adenoid vegetation. An adenotonsillectomy operation was planned. After a successful surgical intervention, on the third postoperative day, the patient was admitted to the otorhinolaryngology clinic with the 
complaints of the neck leaning to one side and painful neck movements. Oropharyngeal examination revealed no evidence of infection. A severe spasm of the right sternocleidomastoid muscle was observed. A neurology consultation was requested, and the results of a neurological examination were normal. There was no history of trauma after the operation. For further investigation, a cervical vertebrae $\mathrm{X}$-ray was obtained in the anteriorposterior (open-mouth) and lateral projections. The X-ray images demonstrated a widened atlantodental interval and anterior displacement of the cervical $\mathrm{Cl}$ and $\mathrm{C} 2$ vertebrae bodies (Fig. Ia). According to these findings, the radiologists recommended cervical computed tomography (CT). A cervical CT scan confirmed the widening of the atlantodental interval and anterior displacement of the $\mathrm{Cl}$ and C2 vertebrae bodies (Fig. Ib). CT images also showed a widened space between the dens and left $\mathrm{Cl}$ lateral mass,

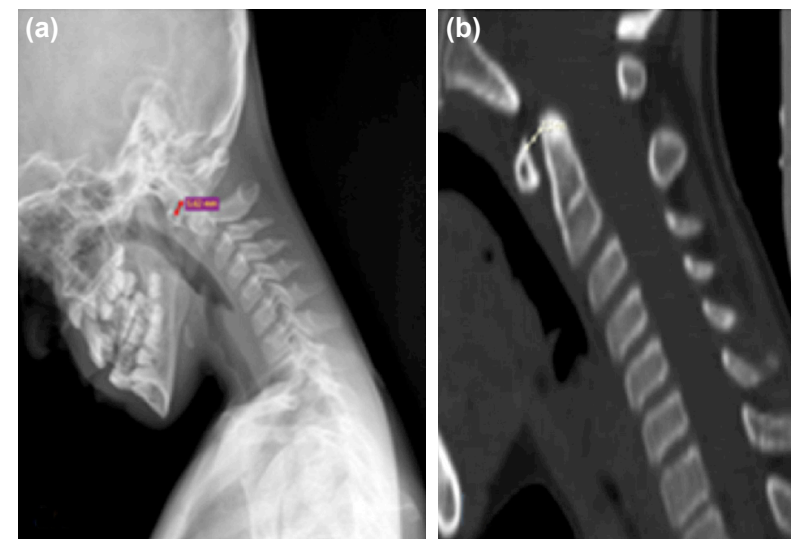

Figure 1. (a) Lateral radiograph of the cervical spine obtained in the flexion position, and (b) sagittal computed tomography (CT) image shows widened atlantodental interval and anterior displacement of $\mathrm{C} 1$ and $\mathrm{C} 2$ vertebrae bodies on the C3 vertebra body.
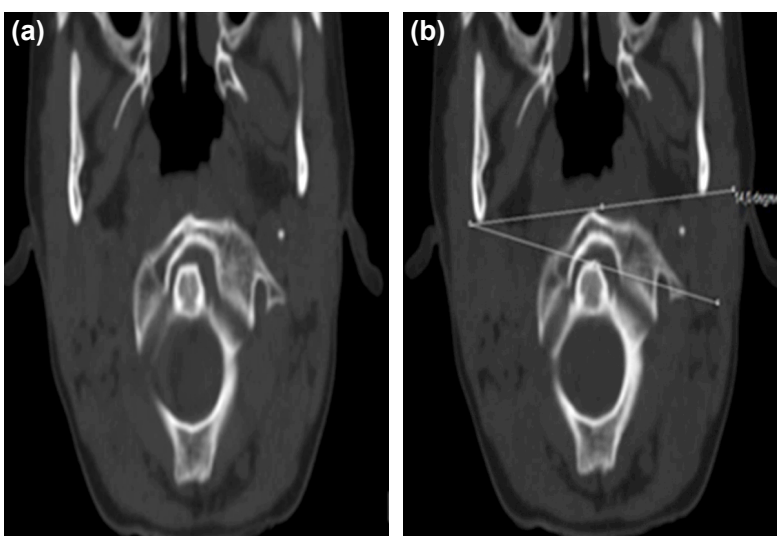

Figure 2. (a) Axial computed tomography image illustrating widened space between the dens and the left $\mathrm{C} 1$ lateral mass. The atlas is rotated on a lateral articular process with $5.2 \mathrm{~mm}$ of anterior displacement consistent with type II atlantoaxial rotatory fixation. (b) $\mathrm{C} 1$ vertebrae turned to the left and subluxation of $14^{\circ}$ on the occipital condyle. and rotation of the atlas on the lateral articular process with $5.2 \mathrm{~mm}$ of anterior displacement consistent with type II atlantoaxial rotatory fixation (AARF) (Fig. 2a). The CI vertebrae were turned to the left, and subluxation on the occipital condyle of $14^{\circ}$ was seen (Fig. 2b). Following a consultation with a neurosurgeon, a Philadelphia cervical collar, arms, antibiotherapy, and anti-inflammatory treatment were applied for 2 weeks. At the end of 2 weeks, the torticollis was resolved and the painful neck movements were healed.

\section{DISCUSSION}

The nontraumatic subluxation of the atlantoaxial joint is only rarely seen in the pediatric population after nasopharyngeal inflammation or otolaryngological surgery, and its pathogenesis is not fully understood..$^{[3]}$

The primary stabilizer of the atlantoaxial joint is the transverse ligament, attached to the lateral posterior portion of the anterior arch of the atlas and forming the posterior support of the odontoid process and preventing excessive shifts of the $\mathrm{Cl}$ to the $\mathrm{C} 2$. The alar ligaments are secondary stabilizers, preventing excessive rotation. Historically, 3 main theories have been emphasized to explain the pathogenesis of Grisel's syndrome: metastatic inflammatory effusion as a result of ligamentous stress, subluxation as a result of muscle spasms, and increased local blood flow and decalcification of the connection point of the transverse ligament. ${ }^{[4]}$

Grisel's syndrome is graded according to the Fielding classification, based on the degree of displacement of the atlas on the axis determined by radiological examination. ${ }^{[5]}$ The Fielding classification of atlantoaxial rotatory fixation includes 4 types: Type I, simple rotatory displacement without anterior shift, the transvers ligament is intact and the dens acts as a pivot point; type 2, rotatory and anterior displacement between 3 and $5 \mathrm{~mm}$, the transverse ligament is injured and the opposite facet acts as a pivot point; type 3, rotatory and anterior displacement greater than 5 $\mathrm{mm}$ with both lateral atlantoaxial joints anteriorly subluxated, and the transverse and alar ligaments are injured; and type 4 , subluxation of the both lateral atlantoaxial joints. ${ }^{[2]}$

Although Grisel's syndrome was first described in the 1830s, there has been long-standing and unresolved controversy regarding the pathogenesis, diagnosis, and the best treatment modalities for the syndrome. There is no universally accepted treatment model. Some authors ${ }^{[6]}$ suggest conservative treatment (immobilization, antibiotics, resting, and analgesics) for types $I$ and 2 (cervical traction and muscle relaxants in addition to type I) and more invasive methods (halo immobilization arthrodesis and $\mathrm{Cl}-\mathrm{C} 2$ cervical fusion) for types 3 and 4 . Wetzel and Lorracca $^{[7]}$ proposed another treatment algorithm: a soft 
cervical collar for type I, rigid arms for type 2, close fixation with halo for type 3 , and open fixation with halo for type 4.

The goal of treatment of Grisel's syndrome is to prevent bone deformities and to treat infectious disease and prevent neurological sequelae. All of these treatment modalities can be personalized to the patient. In our case, we applied antibiotherapy for 10 days, a soft cervical collar, and 2 weeks of resting as analgesic treatment for type 2 subluxation. After 2 weeks, we observed complete recovery.

Grisel's syndrome is a rare condition. In patients who have painful torticollis after an upper airway infection or otolaryngological surgery, Grisel's syndrome should be suspected. The most important factor affecting the prognosis is early diagnosis and treatment. Early diagnosis not only allows for conservative treatment, but also prevents permanent neck deformity and the development of severe neurological deficits and morbidity due to extensive surgical procedures. Otolaryngologists should be aware of this rare, but potentially serious, condition. ${ }^{[8]}$

\section{Informed Consent}

Written informed consent was obtained from the patient for the publication of the case report and the accompanying images.

Peer-review

Internally peer-reviewed.
Conflict of Interest

None declared.

\section{REFERENCES}

1. Barcelos AC, Patriota GC, Netto AU. Nontraumatic Atlantoaxial Rotatory Subluxation: Grisel Syndrome. Case Report and Literature Review. Global Spine J 2014;4:179-86. [CrossRef]

2. Bocciolini C, Dall'Olio D, Cunsolo E, Cavazzuti PP, Laudadio P. Grisel's Syndrome: a Rare Complication Following Adenoidectomy. Acta Otorhinolaryngol Ital 2005;25:245-9.

3. Spennato $P$, Nicosia G, Rapanà $A$, Cicala $D$, Donnianni $T$, Scala $S$, et al. Grisel Syndrome Following Adenoidectomy: Surgical Management in a Case with Delayed Diagnosis. World Neurosurg 2015;84:1494.e7-12. [CrossRef]

4. Ugur HC, Cağlar S, Unlu A, Erdem A, Kanpolat Y. Infection-related atlantoaxial subluxation in two adults: Grisel syndrome or not? Acta Neurochir (Wien) 2003;145:69-72. [CrossRef]

5. Ortega-Evangelio G, Alcon JJ, Alvarez-Pitti J, Sebastia V, Juncos M, Lurbe E. Eponym: Grisel syndrome. Eur J Pediatr 2011;170:965-8.

6. Park SH, Park SH, Lee SH. Grisel Syndrome: Pathophysiological Evidence from Magnetic Resonance Imaging Findings. Ann Rehabil Med 2013;37:713-6.

7. Wetzel FD, LaRocca H. Grisel's syndrome. Clin Orthop Relat Res 1989:141-52.

8. Aladag Ciftdemir N, Eren T, Ciftdemir M. A Rare Cause of Torticollis: Grisel Syndrome. J Trop Pediatr 2017;10:1093. [CrossRef]

\section{Adenotonsillektomi Sonrası Gelişen Nadir Bir Komplikasyon: Grisel Sendromu}

Grisel sendromu olarak da adlandırılan non travmatik atlantoaksiyel subluksasyon otolaringolojik cerrahi ve nazofarengeal enflamasyon sonrasında nadir olarak pediyatrik popülasyonda görülür. Hastalar genellikle 5-12 yaş araalığındadır ve cinsiyet farkı yoktur. Üst solunum yolu enfeksiyonu veya çeşitli otolaringolojik cerrahi sonrasında ağrılı tortikolis bulunan hastalarda Grisel sendromundan şüphelenilmelidir. Prognozu etkileyen en önemli faktör erken tanı ve tedavidir. Erken tanı konservatif tedaviye olanak vermesinin yanında kalıcı boyun deformitesini, ciddi nörolojik defisit gelişmesini ve geniş cerrahi prosedürlere bağlı morbidite gelişimini de önlemektedir. Otolaringologlar nadir fakat potansiyel olarak ciddi olan bu durumun farkında olmalıdırlar.

Anahtar Sözcükler: Atlantoaksiyel subluksasyon; Grisel sendromu; tortikolis. 